\title{
Regionalizace nedostatkových objemů v České republice
}

\section{FILIP STRNAD, VOJTĚCH MORAVEC, MARTIN HANEL, ADAM VIZINA, ADAM BERAN, EVA MELIŠOVÁ, ROMAN KOŽíN}

Klíčová slova: sucho - deficitní objemy - doba opakování - index-flood model

\section{SOUHRN}

Cílem této studie je regionalizace České republiky z hlediska rizika výskytu sucha v jednotlivých povodích. Regionalizace České republiky byla provedena pro sadu 133 (mezi-)povodí pro období 1901-2015. Primárním indexem popisujícím sucho $v$ rámci této studie jsou nedostatkové objemy vzhledem k prahu odpovídajícímu 20\% kvantilu měsíčních průtoků. Na základě srážek, výparu, celkového a základního odtoku a hydrogeologických rajonů byla pomocí shlukové analýzy provedena regionalizace České republiky z hlediska chování v době sucha. Tato regionalizace byla následně expertně revidována. Nedostatkové objemy v simulaci modelu Bilan byly vyčísleny a byl vytvořen statistický model pro odhad N-letých nedostatkových objemů. Charakteristiky sucha v simulaci modelu Bilan pro povodí s dostupnými pozorovanými daty i výsledky statistického modelu byly úspěšně validovány.

\section{ÚVOD}

Odhad charakteristik sucha, včetně regionalizace jeho výskytu, je zatížen značnou nejistotou. Tato nejistota je, oproti analýze extrémních srážek, navíc znásobena skutečností, že sucho se nevyskytuje každý rok a efektivní délka standardně použivaných 30-50letých časových řad je ve skutečnosti přibližně poloviční, významnější sucha se vyskytují pouze v malém zlomku let. Ve studii popsané v tomto článku jsou proto využity dvě strategie pro snížení nejistot odhadů charakteristik sucha.

První spočíá ve využití dlouhých časových řad srážek a teploty (1901-2015), které jsou dostupné $v$ měsíčním kroku a prostorovém rozlišení $0,5^{\circ}$ pro celý svět. Tyto raady, opravené o systematické chyby, slouží jako vstupy do modelu Bilan a výsledná simulace odtoku je analyzována z hlediska charakteristik sucha. Druhá strategie je založena na využití regionální frekvenční analýzy. Tato metoda předpokládá, že rozdělení normovaných extrémů (např. maximálních ročních deficitních objemů) je v homogenních oblastech stejné pro všechna povodí. Normovaným rozdělením extrémů se rozumí rozdělení hodnot vydělených normovacím faktorem (např. průměr nebo jiný parametr polohy daného rozdělení). Kombinací dat z různých povodí tak Ize částečně nejistoty odhadu redukovat.

Následující kapitola stručně popisuje použitá data, studované charakteristiky nedostatkových objemů a jejich validaci. Další kapitola popisuje regionalizaci ČR z hlediska rizika sucha a poslední kapitola prezentuje odhady N-letých nedostatkových objemů.
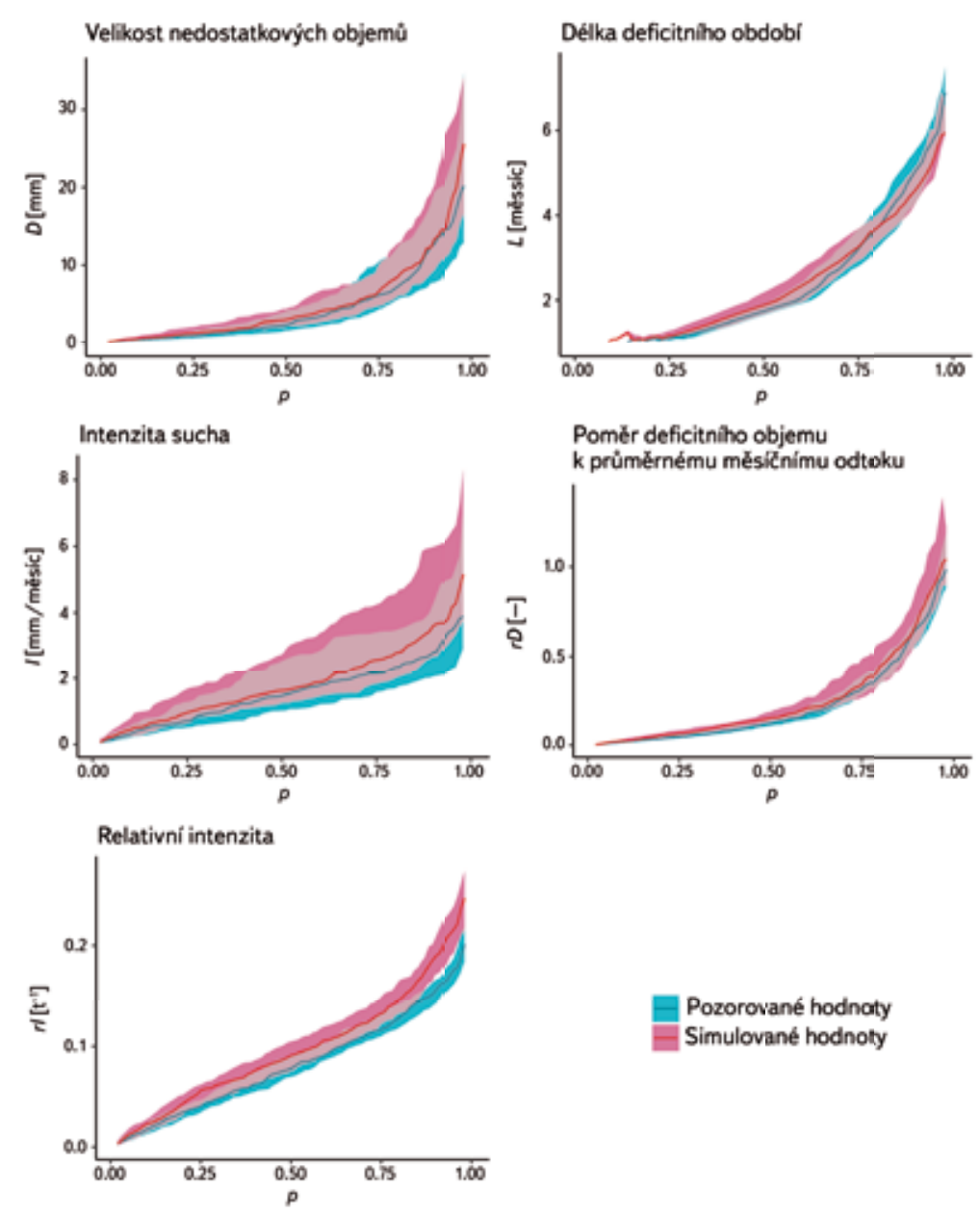

Obr. 1. Porovnání charakteristik sucha pozorovaného a modelovaného průtoku; na ose x je vynesena pravděpodobnost z distribuční funkce jednotlivých charakteristik, na ose y jsou uvedeny hodnoty jednotlivých charakteristik sucha, barevné plochy jsou rozsahy 25\% a $75 \%$ kvantilů hodnot charakteristik ze souboru povodí

Fig. 1. Comparison of drought characteristics for observed and simulated runoff; the horizontal axis shows the probability from the distribution of the individual characteristics, the vertical axis indicate the values of the drought characteristics, the colored polygons correspond to the range between the $25^{\text {th }}$ and $75^{\text {th }}$ percentile of the value of drought characteristics in the set of catchments 


\section{CHARAKTERISTIKY SUCHA}

Pro účely studie je sucho definováno na základě nedostatkových objemů odvozených ze simulované hydrologické bilance pro sadu mezipovodí pro období 1901-2015. Odvozené časové řady měsíčních srážek a teplot na plochy mezipovodí jsou založeny na kombinaci HadCRU-TS3.21 [1], staničních dat a gridovaného datasetu srážek a teploty [2]. Gridovaná data byla převedena na plochu povodí pomocí váženého průměru (podle velikosti průniku plochy povodí a príslušných grid boxů), následně byla u teploty provedena korekce na nadmořskou výšku na základě porovnání nadmořské výšky povodí a průměrné nadmořské výšky grid boxů a korekce srážek na základě vrstvy dlouhodobých průměrných srážek v období 1981-2010. Pomocí těchto časových řad a parametrů modelu Bilan získaných kalibrací na pozorovaných datech byla simulována hydrologická bilance pro celé období 1901-2015.

Nedostatkové objemy jsou definovány jako suma doplňků měsíčních odtoků souvisle pod 20\% kvantilem rozdělení odtoku. Mezi základní charakteristiky nedostatkových objemů Ize zařadit:

A. velikost nedostatkového objemu, $D\left[\mathrm{~mm}\right.$ nebo $\left.\mathrm{m}^{3}\right]$,

B. doba trvání deficitní události, $L$ [měsíce],

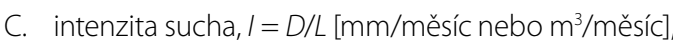

D. poměr deficitního objemu k průměrnému měsíčnímu odtoku, rD [-],

E. relativní intenzita, $r l=r D / L\left[\mathrm{t}^{-1}\right]$.

Podle průměrných hodnot jednotlivých charakteristik sucha $v$ tabulce 1 je žrejmé, že jsou na sobě jednotlivé charakteristiky lineárně závislé. Také Ize pozorovat postupný růst jednotlivých charakteristik v průběhu první (1901-1930) až třetí periody (1961-1990), v poslední periodě (1991-2015) Ize pozorovat jejich pokles.

Tabulka 1. Porovnání prümërných hodnot charakteristik sucha podle jednotlivých period na základě modelovaného celkového odtoku ( $D[\mathrm{~mm}]$ velikost nedostatkových objemü, I [mm/měsíc] intenzita sucha, L [měsíc] délka deficitního období, rD [-] pomèr deficitního objemu k průměrnému měsičnímu odtoku, rl [t'] relativní intenzita)

Table 1. Average drought characteristics for different time periods based on simulated runoff ( $\mathrm{D}[\mathrm{mm}]$ deficit volume, I $[\mathrm{mm} / \mathrm{month}]$ drought intensity, $L[$ month] length of the deficit period, $r D$ [-] ratio of deficit volume to average monthly discharge, rl [ $\left.t^{+}\right]$relative intensity)

\begin{tabular}{llllll} 
Perioda & $\boldsymbol{D}$ & $\boldsymbol{I}$ & $\boldsymbol{L}$ & $\boldsymbol{r} \boldsymbol{D}$ & $\boldsymbol{r l}$ \\
\hline $1901-1930$ & 4,46 & 1,70 & 2,34 & 0,24 & 0,09 \\
\hline $1931-1960$ & 6,01 & 1,97 & 2,76 & 0,36 & 0,11 \\
\hline $1961-1990$ & 6,68 & 2,19 & 2,95 & 0,44 & 0,12 \\
\hline $1991-2015$ & 4,74 & 1,79 & 2,38 & 0,29 & 0,10
\end{tabular}

\section{Validace deficitních objemů}

Validace deficitních objemů probíhala pomocí selekce uzavřených povodí se známým pozorovaným odtokem tak, aby bylo možné porovnat jednotlivé charakteristiky sucha vypočítané na základě modelovaného a zároveň pozorovaného prưtoku. Validaci bylo možno provést na 65 povodích (ze 133).

Jak je možné vidět v tabulce 2, všechny charakteristiky sucha vypočítané na základě simulovaného odtoku jsou pouze mírně vyšší oproti charakteristikám získaným pomocí pozorovaného odtoku.

Obrázek 1 prezentuje porovnání charakteristiky jednotlivých deficitních událostí. Je žrejmé, že model Bilan simuluje důležité charakteristiky sucha dostatečně presně.

Tabulka 2. Porovnání celkových průmèrů charakteristik sucha pro vybraných 65 povodi na základě pozorovaného a simulovaného odtoku $(\mathrm{D}[\mathrm{mm}]$ velikost nedostatkových objemů, I [mm/měsíc] intenzita sucha, L [měsíc] délka deficitního období, rD [-] pomèr deficitního objemu k prüměrnému měsičnímu odtoku, rl [t'] relativní intenzita)

Table 2. Comparison of average drought characteristics in simulated and observed data for 65 catchment with available data $(D[\mathrm{~mm}]$ deficit volume, I [ $\mathrm{mm} / \mathrm{month}]$ drought intensity, L [month] length of the deficit period, $r D$ [-] ratio of deficit volume to average monthly discharge, $r l\left[t^{1}\right]$ relative intensity)

\begin{tabular}{llllll} 
Odtok & $\boldsymbol{D}$ & $\boldsymbol{I}$ & $\boldsymbol{L}$ & $\boldsymbol{r} \boldsymbol{D}$ & $\boldsymbol{r l}$ \\
\hline Pozorovaný odtok & 5,25 & 1,94 & 2,29 & 0,24 & 0,09 \\
\hline Simulovaný odtok & 6,15 & 2,35 & 2,36 & 0,28 & 0,10
\end{tabular}

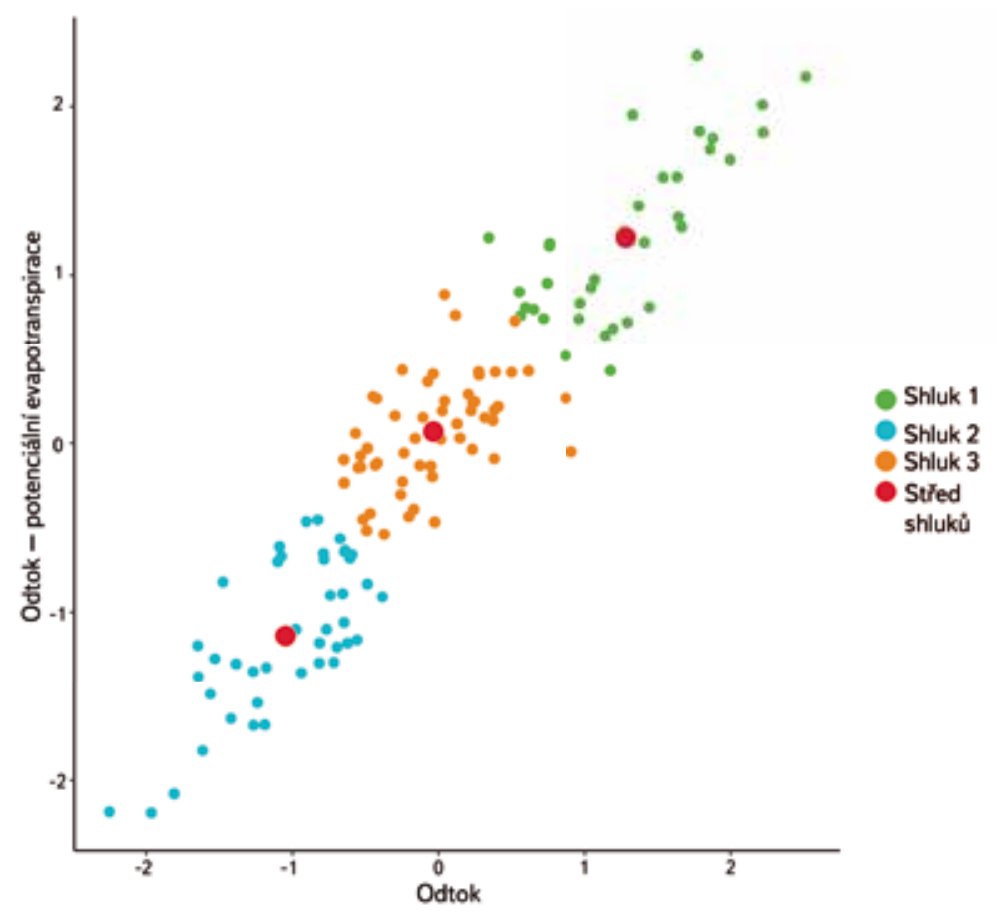

Obr. 2. Výsledné shluky (barevně) a jejich středy (lokální optima) Fig. 2. Resulting clusters (colors) and their centers (bold dots) 


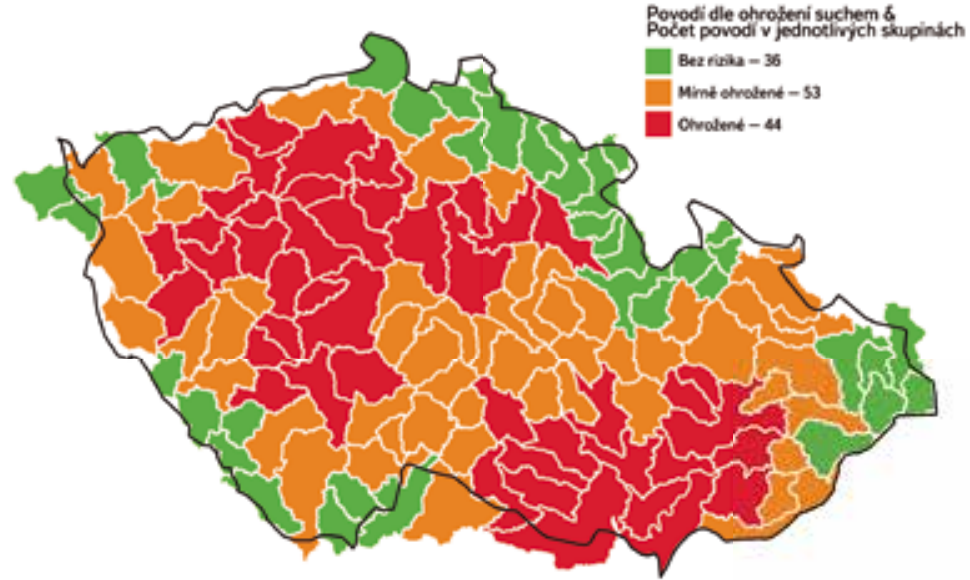

Obr. 3. Výsledky regionalizace

Fig. 3. Resulting regionalization

\section{REGIONALIZACE ČR Z HLEDISKA VÝSKYTU SUCHA}

Ze všech fází regionalizace je identifikace homogenních oblastí zpravidla nejobtížnější a vyžaduje velké množství subjektivních rozhodnutí. Pro identifikaci homogenních oblastí byl využit algoritmus K-means [3], jehož cílem je nalezení shluků $v$ datasetu. Vstupem algoritmu je množina bodů, které jsou definované souřadnicemi v n-rozměrném prostoru, a číslo $k$, určující požadovaný počet shluků. Všechny shluky jsou reprezentované svými středy a každý bod náleží do shluku, jehož střed je mu nejblíže. Souřadnice středů se určují iterativním způsobem, tento iterativní algoritmus neustále zmenšuje chybu, definovanou jako součet vzdáleností všech bodů od středů svých shluků, a spěje tak k lokálně-optimálnímu řešení. Shluková analýza pro povrchový odtok proběhla se škálovanými daty průměrných odtoků a rozdílů odtoků a potenciální evapotranspirace (tj. ve dvourozměrné metrice [odtok; odtok - PET]), algoritmus proběhl celkově desetkrát, pokaždé se startem v jiné, náhodné pozici. Do padesáti iterací každý běh konvergoval k lokálně-optimálnímu řešení, výsledné shluky a jejich středy jsou zobrazeny na obr. 2 a výsledná regionalizace pak na obr. 3.
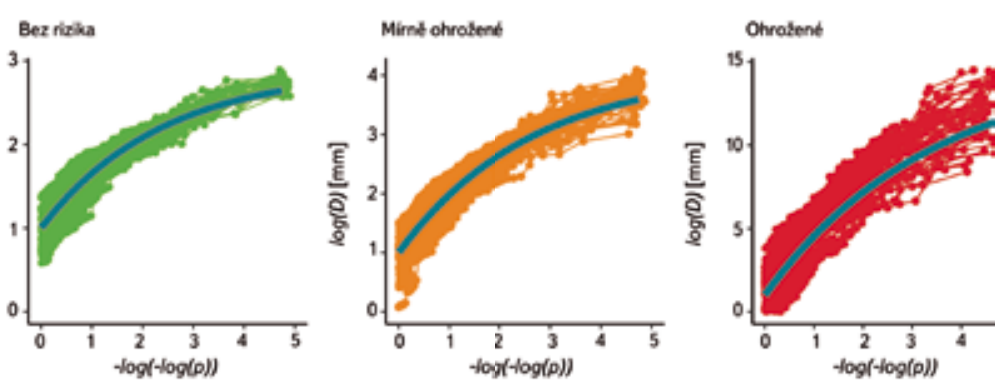

Obr. 4. Regionální kvantilové funkce pro jednotlivé oblasti (tlustá čára) spolu s normovanými kvantilovými funkcemi pro pozorovaná data z jednotlivých (mezi-)povodí Fig. 4. Regional quantile functions for individual regions (bold line) together with standardized quantile functions for the observed data from individual catchments

\section{REGIONÁLNÍ EXTREMÁLNÍ MODEL PRO NEDOSTATKOVÉ OBJEMY}

Odhad N-letých nedostatkových objemů je zatí̌en značnou nejistotou, vyplývající mj. z délky dostupných řad. Podobně jako pro extrémní průtoky a srážky Ize i pro nedostatkové objemy využít tzv. index-flood metodu. Předpokladem je, že nedostatkové objemy v každém (mezi-)povodí v rámci předem definované oblasti mohou být normovány tak, že rozdělení těchto normovaných nedostatkových objemů je $v$ dané oblasti stejné. Normovací faktor, který je určen pro jednotlivá (mezi-)povodí, je zpravidla označován index-flood, stejně jako tato metoda [4]. Primárně uvažujeme, že nedostatkové objemy v jednotlivých povodích Ize popsat pomocí zobecněného rozdělení extrémních hodnot (Generalized Extreme Value Distribution - GEV). Rozdělení je korigováno vzhledem k výskytu let bez sucha na základě vztahu, který uvádí Engeland [5].

Výsledkem optimalizace modelu jsou normovací faktory pro jednotlivá povodí a regionální kvantilová funkce. Detaily modelu popisuje Hanel [6]. Regionální kvantilové funkce spolu s normovanými nedostatkovými objemy pro jednotlivá povodí uvádí obr. 4. Pravděpodobnosti $p$ jsou transformované pomocí vztahu - $\log (-\log (p))$. Tato transformace zajištuje lepší zobrazení extrémů s vysokou dobou opakování.

Na obr. 5 jsou uvedeny odhady 2, 5, 10, 20 a 50letého nedostatkového objemu [mm] pro celkový odtok. Je zjevné, že nedostatkové objemy jsou do jisté míry korelované s celkovým odtokem. $V$ relativním vyjádření vzhledem k průměrnému celkovému odtoku (obr.6) nedostatkové objemy rostou s dobou opakování (platí i v absolutní hodnotě) a zřetelně je vidět větší dopad na povodí v oblasti 3 (tj. v oblasti s nejvyšším rizikem výskytu sucha). 

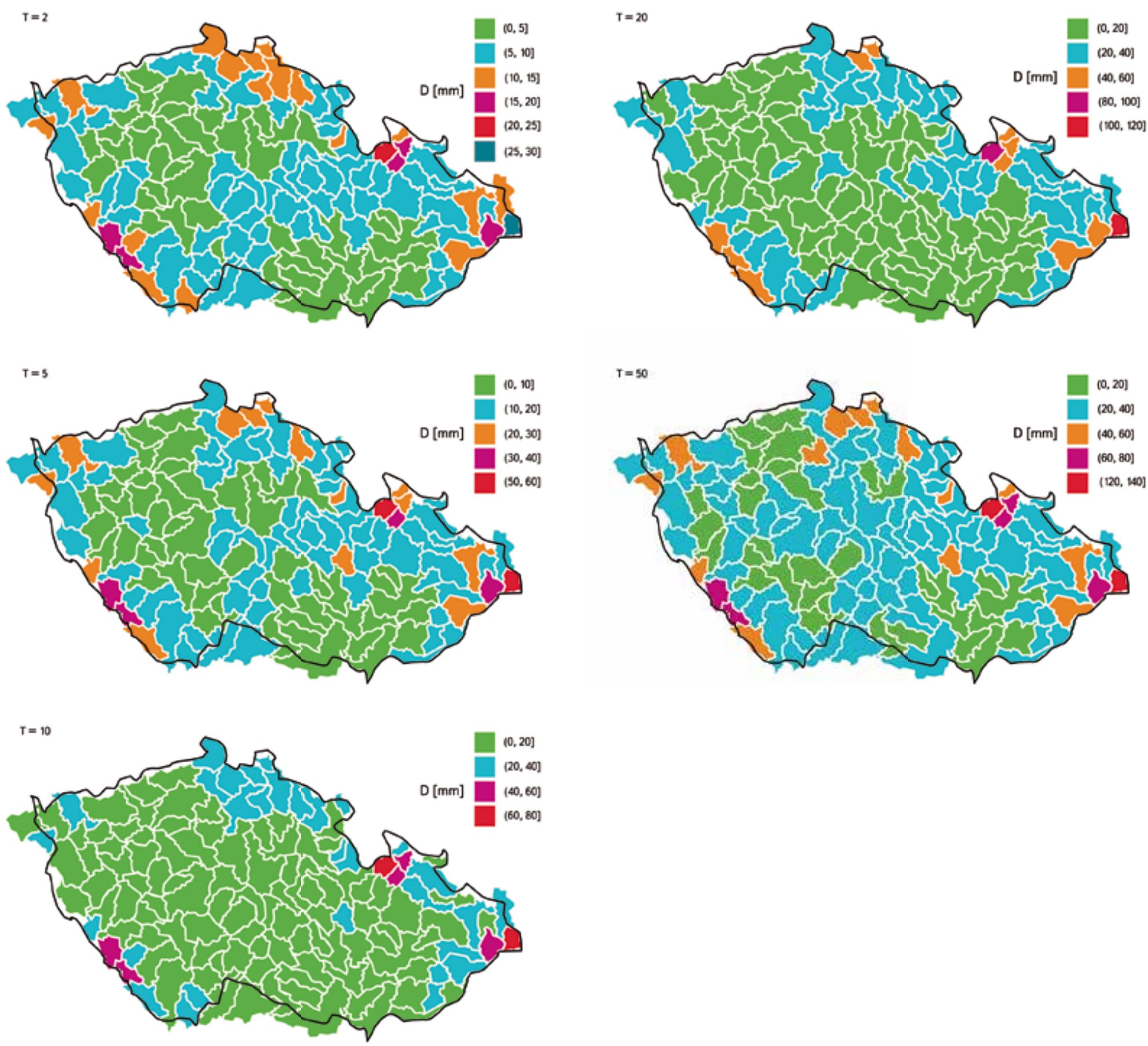

Obr. 5. Mapa N-letých nedostatkových objemů pro (simulovaný) celkový odtok pro 2, 5, 10, 20, 50 let

Fig. 5. Map of N-year deficit volumes for (simulated) total runoff for 2, 5, 10, 20, 50 years 
$T=2$

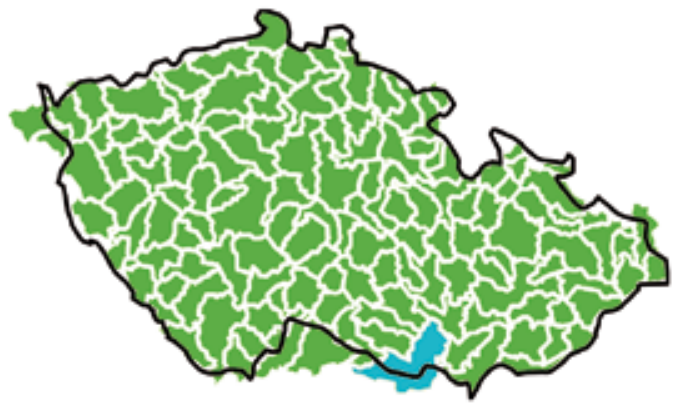

$T=20$

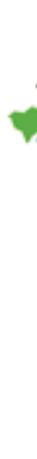

$T=5$

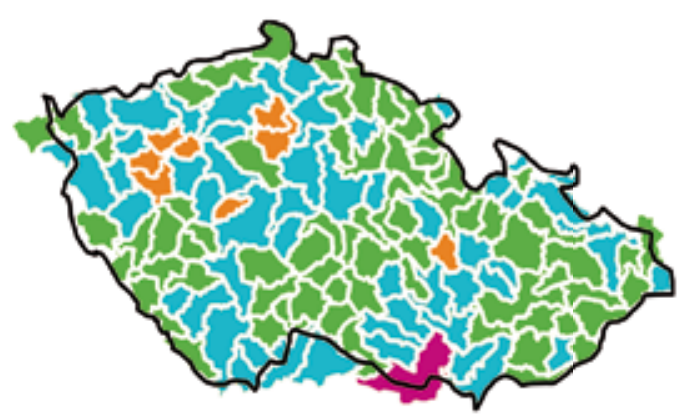

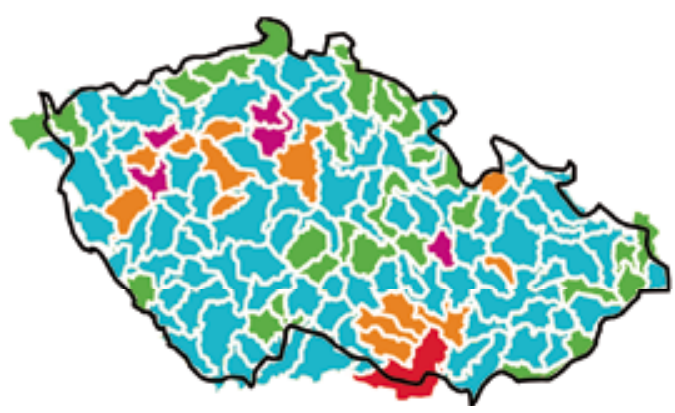

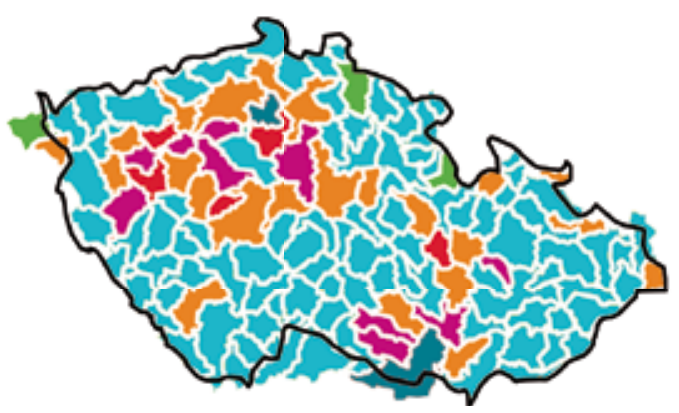

$\mathrm{rD}[-]$

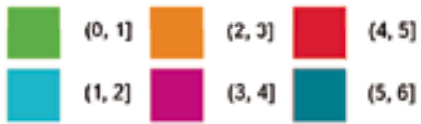

Obr. 6. Poměr deficitního objemu k průměrnému měsíčnímu odtoku pro doby opakování 2, 5, 10, 20, 50 let

Fig. 6. Ratio of deficit volume to mean monthly runoff for 2, 5, 10, 20, 50 years return periods

\section{ZÁVĚR}

Hydrologický model Bilan byl použit pro simulaci hydrologické bilance 133 mezipovodí v ČR pro období 1901-2015. Bylo ukázáno, že simulované charakteristiky sucha odpovídají dobře charakteristikám pozorovaným (pro povodí, pro která jsou dostupná data). Území ČR bylo rozděleno do tři homogenních oblastí označovaných „bez rizika“ (horské polohy) „ "mírně ohrožené” (Vysočina a střední polohy) a "ohrožené" (nížiny - zejména jižní Morava a střední Čechy). Byly odhadnuty parametry statistického modelu umožňujícího vyčíslení N-letých nedostatkových objemů. Z hlediska rozdělení nedostatkových objemů se jednotlivé oblasti liší zejména variabilitou sucha - oblasti označované „bez rizika” mají poměrně vyrovnaný režim a nedostatkové objemy v jednotlivých suchých obdobích se př́liš neliší. Naopak v oblastech označovaných jako "ohrožené" je velký rozdíl mezi různě extrémními suchy - tj. rozdíl mezi 2letým a 10letým suchem je zde podstatně větší než v ostatních oblastech.

Dalšími kroky v regionalizaci hydrologického sucha v ČR je zjemnění prostorového měřitka použitého pro regionalizaci a odhad N-letých nedostatkových objemů až na povodí útvarů povrchových vod, vyhodnocení jednotlivých historických prípadů sucha, prodloužení rekonstrukce dále do minulosti, simulace podmínek ovlivněných klimatickou změnou a vyhodnocení nejistot.

\section{Poděkování}

Studie byla provedena v rámci úkolu Činnosti k podpoře výkonu státní správy v problematice sucho $v$ roce 2016 a vnitřnich grantů Fakulty životního prostředí ČZU c. 20164230 (FS) a 20174227 (VM).

\section{Literatura}

[1] HARRIS, I., JONES, P.D., OSBORN, T.J., and LISTER, D.H. Updated high-resolution grids of monthly climatic observations-the CRU TS3, 10 Dataset. International Journal of Climatology, 2014, vol. 34, No. 3, p. 623-642.

[2] ŠTĚPÁNEK, P., ZAHRADNÍČEK, P., and HUTH, R. Interpolation techniques used for data quality control and calculation of technical series: an example of Central European daily time series. Idöjárás, 2011, vol. 115, No. 1-2, p. 87-98

[3] HARTIGAN, J.A. and WONG, M.A. Algorithm AS 136: A k-means clustering algorithm. Journal of the Royal Statistical Society. Series C (Applied Statistics), 1979, vol. 28, No.1, p. 100-108.

[4] HOSKING, J.R.M. and WALLIS, J.R. Regional frequency analysis: an approach based on Lmoments. Cambridge University Press, 1997.

[5] ENGELAND, K., HISDAL, H., and FRIGESSI, A. Practical extreme value modelling of hydrological floods and droughts: A case study. Extremes, 2004, vol. 7, No. 1, p. 5-30.

[6] HANEL, M., BUISHAND, T.A., and FERRO, C.A.T. A nonstationary index flood model for precipitation extremes in transient regional climate model simulations. Journal of Geophysical Research, 2009, vol. 114, No. D15. 
Autoři

Ing. Filip Strnad

凶strnadf@fzp.czu.cz

Ing. Vojtěch Moravec

凶vmoravec@fzp.czu.cz

doc. Ing. Martin Hanel, Ph.D.,

凶martin.hanel@vuv.cz

Ing. Adam Vizina, Ph.D.,

凶adam.vizina@vuv.cz

Ing. Adam Beran ${ }^{1,2}$

凶adam.beran@vuv.cz

Ing. Eva Melišová1,2

凶eva.melisova@vuv.cz

Ing. Roman Kožín ${ }^{1,2}$

凶roman.kozin@vuv.cz

'Fakulta životního prostředí, Česká zemědělská univerzita ${ }^{2}$ Výzkumný ústav vodohospodářský T. G. Masaryka, v. v. i.

\section{REGIONALIZATION OF DEFICIT RUNOFF VOLUMES IN THE CZECH REPUBLIC}

\section{STRNAD, F. ${ }^{1}$; MORAVEC, V. ${ }^{1}$; HANEL, M. ${ }^{1,2}$; VIZINA, A. ${ }^{1,2}$; BERAN, A. ${ }^{1,2}$; MELISOVA, E. ${ }^{1,2}$; KOZIN, R.,}

${ }^{1}$ Faculty of Environmental Sciences, Czech University of Life Sciences Prague ${ }^{2}$ TGM Water Research Institute, p. r. i.

Keywords: drought - deficit volume - return period - index-flood model

The aim of the study is the regionalization of the Czech Republic with respect to drought characteristics in individual catchments. The regionalization was done for a set of 133 catchments and for the period 1901-2015. The basic index describing the hydrological drought is the deficit discharge, i.e. the cumulative volume bellow $20^{\text {th }}$ percentile of the monthly runoff distribution. The regionalization of drought characteristics was based on the mean precipitation, evaporation, total and base flow and hydrogeological districts. This regionalization was revised by experts. The deficit volumes in the simulation of the Bilan model were estimated and the statistical model for estimation of $\mathrm{N}$-year deficit volumes was developed and validated

Příspěvek prošel lektorským řízením.

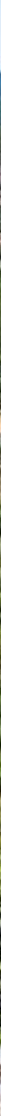

